\title{
Evaluation of growth traits of Aceh cattle at the breeding station in Indrapuri District of I ndonesia
}

\author{
WPB Putra*1, Sumadi², T Hartatik ${ }^{2}$, H Saumar ${ }^{3}$
}

${ }^{1}$ Division of Animal Breeding, Indonesian Institute of Sciences, Bogor, Indonesia, 16916; ${ }^{2}$ Faculty of Animal Science, Gadjah Mada University, Yogyakarta, Indonesia 55281; ${ }^{3}$ Indrapuri's Breeding and

Forages Center (IBFC) of Aceh Cattle, Aceh, Indonesia 23363

\begin{abstract}
The present study was conducted using records on four breeding bulls maintained at the Indrapuri's Breeding and Forages Center (IBFC) of Aceh Cattle, Indrapuri district, Indonesia and 52 of their progeny born from 2010 to 2014 through natural mating. Family selection was practiced in this breeding station. Traits included in this study were birth weight at 0 day (BWC), weaning weight at 205 days of age (WWc), yearling weight at 365 days of age (YWc) and final weight at 550 days of age (FWc) of their progeny. The variance and covariance components were estimated by the Paternal Half-sib Correlation method with the Excel sheets of Microsoft office computer program. The mean body weights of the animals were BWc $(13.25 \pm 1.18 \mathrm{~kg})$, WWC $(47.80 \pm 10.00 \mathrm{~kg})$, YWc $(73.97 \pm 16.79 \mathrm{~kg})$ and FWc $(101.87 \pm 23.91 \mathrm{~kg})$. Estimated heritability $\left(h^{2}\right)$ for $B W_{c}$ was low $\left(h^{2} \leq 0.10\right)$ and the other traits were high $\left(h^{2} \geq 0.30\right)$. Higher standard error (SE) value than $h^{2}$ caused by less number of calves observation. Research showed that best relative accuracy value $(R A>1.00)$ reached in $B W_{C}$. but its trait was not effective as selection criterion because of lower $h^{2}$ value. It was concluded that $W W_{c}$ could be used as selection criterion for breeding bulls based on the similar estimated breeding value (EBV) rank and high $\mathrm{h}^{2}$ value. The EBV of $\mathrm{WW}_{\mathrm{C}}$ from breeding bull ID: 0752 was calculated and ranked accordingly. The EBVs of three top bulls ID were $100412(10.32 \mathrm{~kg}), 100520(9.38 \mathrm{~kg})$ and $100317(6.75 \mathrm{~kg})$ and three top heifers were $100526(9.65 \mathrm{~kg}), 100408(7.04 \mathrm{~kg})$ and $100807(5.20 \mathrm{~kg})$. It can be concluded that these top ranking three bulls and heifers can be selected and used in the breeding programs.
\end{abstract}

Key words: Aceh cattle, progeny, body weights, heritability, estimated breeding value

Bangladesh Animal Husbandry Association. All rights reserved.

Bang. J. Anim. Sci. 2015. 44(2): 85-91

\section{Introduction}

Cattle farming and its development has ever ending need in Indonesia as they are inseparable and integral part of agricultural farming system in Indonesia. In the country, there are about 14.90 million, contributing more than $4.80 \%$ to the national GDP (Umartha 2013). About $40 \%$ or 31 million people of the country are directly or indirectly engaged in livestock and poultry business. Aceh cattle are one of several Indonesian native cattle that plays major role for beef production. This type of cattle adapts well to Indonesian environment, tropical climate and able to live on feedstuff. The population size of
Aceh cattle is recorded 483.628 in 2013 and concentrated at Aceh province. Aceh cattle account for approximately $3 \%$ of the total cattle population in Indonesia (Umartha 2013). Even though Aceh cattle were able to adapt well, their productivity is still lower than other Indonesian local cattle. By improving the productivity of Aceh cattle, it is hoped that the breeders interest to breed Aceh cattle will increase, so that the population size of Aceh cattle will increase and may reduce Indonesian dependency on beef and cattle from other countries. However, until recently national attention has been paid to the perceived weaknesses of Aceh cattle, such as 


\section{Evaluation of Aceh Cattle}

high calf mortality, small body size and slow growth rate. Artificial insemination ( $\mathrm{Al}$ ) of Aceh cows/heifers using Aceh semen has become popular in Aceh province since 2013 following significant achievement in improving the cattle breeding system. The government and nongovernment organizations are trying to spread it all over the Aceh province. However, superior bull selection is key to get superior progeny through both of natural mating and Al. For the dissemination of cattle, good breeding bulls are required. There is severe shortfall of quality breeding bulls all over the country, especially in the rural areas, where more than $75 \%$ bulls are being reared by the farmers. Same bulls have been used years after years which have created higher chance of increased level of inbreeding hence likely to lower productivity and reproductive performance (Warwick et al. 1990). In order to improve the genetic make-up of cattle it is important to study growth traits as these enhance proper selection of proven bulls. Among the growth traits, adult weight plays major role in determining meat productivity of livestock production (Falconer and Mackay 1996). The adult weight in relation to meat production is determined by higher birth, weaning and yearling weights. Heritability estimates of growth traits are important because the estimates will determine if genetic selection is posible and the speed at which progress can be made through selection. Growth traits are easily measured and have medium to high heritability (Warwick et al. 1990) suggesting that these traits are likely to respond to selection. Ranking seed stock on their estimated breeding value (EBV) sorts them based on progeny's expected profitability for the targeted production system. In view of all these situations, present study was undertaken to evaluate the Aceh breeding bulls based on growth performance of their progeny in the breeding center.

\section{Materials and Methods}

\section{Experimental animals and period}

The experiment was conducted at the Indrapuri's Breeding and Forages Center (IBFC) of Aceh Cattle, Indrapuri district, Aceh Besar regency, Aceh province, Indonesia. Four Aceh breeding bulls and 52 of their progeny at the breeding centre produced from those breeding bulls and 52 cows constituted the experimental animals. Age and body condition score (BCS) of cows in the present study were 3 years old and 3.0 respectively. The data on progeny birth weight (BWC), weaning weight (WWC), yearling weight (YWC) and final weight (FWc) were collected. Weight measurements taken on each animal using a digital weighing scale every three months. Data on calves produced from the breeding bulls during the period from January 2010 to December 2014 were collected from the herd book maintained at the breeding center for analysis.

\section{Calf management}

The calves were reared in colony stall at the breeding center. They were provided green grass (Pennisetum purpureum) and water ad libitum. The concentrate feeds ( $2 \mathrm{~kg} /$ day/head) were also supplied to them twice daily in the morning (09.30 am) and evening (16.00 pm) for each calf. The concentrate was made from coconut meal (32 \%), rice bran (31 \%), sago (Metroxylon sagu) meal (32\%), salt (2\%), mineral (2\%) and urea (1 \%). Regular vaccination and medication were performed. In general ear tag was used for identification of calves, however, in some cases neck bands were used for new born calves.

\section{Bull and heifer management}

The breeding bulls ( 3 years) and heifers ( 2.5 years) were kept in the individual stall and colony stall respectively. Natural mating was used in this breeding station by ratio 1 breeding bull per 20 heifers in the each breeding stall. All pregnant heifers (cows) were managed in the pasture field (ranch) from morning (09.30 am) to evening (17.00 pm) Calves were born and grown in the pasture field. Therefore, weaning calves were maintained in colony stall until they reached final weight ( 1.5 years old). The concentrate feed ( 4 $\mathrm{kg} /$ day/head) were also supplied to them twice daily in the morning (08.30 am) and evening (16.00 pm) at the colony stall. Fresh water was provided ad libitum. Nutrient standard for Aceh bulls and cows are presented in Table 1 . 
Putra el al. (2015) Bang. J. Amin. Sci. 44(2): 85- 91

\section{Calf performance data}

Birth, weaning, yearling and adult weights of calves were corrected based on formula by Hardjosubroto (1994).

$\mathrm{BW}_{\mathrm{C}}=\mathrm{BW} \times \mathrm{CF}_{\mathrm{BW}}$

and

$\mathrm{CF}_{\mathrm{BW}}=\frac{\mathrm{BW} \text { of male calf }}{\mathrm{BW} \text { of female calf }}$

where, $\mathrm{BW}=$ corrected birth weight, BW = actual birth weight, $\mathrm{CF}_{\mathrm{BW}}=$ correction factor of birth weight for female calf

$\mathrm{WW}_{\mathrm{C}}=\left(\frac{(\mathrm{WW}-\mathrm{BW})}{\mathrm{T}} \times 205+\mathrm{BW}\right) \times \mathrm{CF}_{\mathrm{WW}}$

and

$\mathrm{CF}_{\mathrm{ww}}=\frac{\mathrm{WW} \text { of male calfl }}{\mathrm{WW} \text { of female calf }}$

where, WWc $=$ weaning weight at 205 days, WW $=$ actual weaning weight, BW $=$ actual birth weight, $\mathrm{T}=$ weaning weight in a day, $\mathrm{CF}_{\mathrm{ww}}=$ correction factor of weaning weight for female calf.

$\mathrm{YW}_{\mathrm{C}}=\left(\frac{(\mathrm{W}-\mathrm{WW})}{\mathrm{T}} \times 160+\mathrm{WW}_{\mathrm{C}}\right) \times \mathrm{CF}_{\mathrm{YW}}$

and

$\mathrm{CF}_{\mathrm{YW}}=\frac{\mathrm{YW} \text { of bull }}{\mathrm{YW} \text { of heifer }}$

where, $\mathrm{YWC}=$ yearling weight at 365 days, WW $=$ actual weaning weight, $W W c=$ weaning weight at 205 days, $\mathrm{W}=$ weight when measured, $\mathrm{T}=$ interval time between weaning to measurement, $\mathrm{CF}_{\mathrm{yw}}=$ correction factor of yearling weight for heifer.

$\mathrm{FW}_{\mathrm{C}}=\left(\frac{(\mathrm{W}-\mathrm{WW})}{\mathrm{T}} \times 345+\mathrm{WW}_{\mathrm{C}}\right) \times \mathrm{CF}_{\mathrm{AW}}$

and

$\mathrm{CF}_{\mathrm{AW}}=\frac{\mathrm{AW} \text { of bull }}{\mathrm{AW} \text { of heifer }}$

where, $F W c=$ final weight at 550 days, WW = actual weaning weight, $W W c=$ weaning weight at 205 days, $\mathrm{W}=$ weight when measurement, $\mathrm{T}=$ interval time between yearling to measurement, $\mathrm{CF}_{\mathrm{AW}}=$ correction factor of adult weight for heifer.

\section{Statistical analysis}

The analysis of variances following Paternal Halfsib Correlation method was carried out using Microsoft Office Excel 2003 computer program. A pedigree file was constructed for estimating the heritability of growth traits based on Becker (1992):

$$
\begin{aligned}
& \mathrm{h}^{2}=\frac{4 \hat{\sigma}_{\mathrm{S}}^{2}}{\hat{\sigma}_{\mathrm{S}}^{2}+\hat{\sigma}_{\mathrm{W}}^{2}} \\
& \quad \mathrm{SE}=4 \sqrt{\frac{2(1-\mathrm{t})^{2}[1+(\mathrm{k}-1)(\mathrm{t})]^{2}}{\mathrm{k}(\mathrm{k}-1)(\mathrm{S}-1)}} \\
& \mathrm{t}=\frac{\sigma_{\mathrm{S}}^{2}}{\sigma_{\mathrm{S}}^{2}+\sigma_{\mathrm{W}}^{2}}
\end{aligned}
$$

where, $\mathrm{h}^{2}=$ heritability, $\hat{\sigma}_{S}^{2}=$ variance component of sire, $\hat{\sigma}_{\mathrm{W}}^{2}=$ variance component of progeny, SE $=$ standard error for heritability, $\mathrm{k}=$ number of progeny per sire, $\mathrm{S}=$ number of sire

Estimated breeding values of bulls and their relative accuracy was estimated using Hardjosubroto (1994):

$$
\begin{aligned}
& \mathrm{EBV}=\frac{2 \mathrm{nh}^{2}}{4+(\mathrm{n}-1) \mathrm{h}^{2}}(\overline{\mathrm{P}}-\overline{\overline{\mathrm{P}}})+\overline{\overline{\mathrm{P}}} \\
& \mathrm{RA}=\frac{1}{2} \sqrt{\frac{\mathrm{n}}{1+(\mathrm{n}-1) \mathrm{t}}} \quad \mathrm{t}=\mathrm{Rh}^{2}+\mathrm{c}
\end{aligned}
$$

Estimated breeding value for candidate bulls and heifers (offspring) was estimated using formula by Hardjosubroto (1994):

$\mathrm{EBV}=\mathrm{h}^{2}(\mathrm{P}-\overline{\overline{\mathrm{P}}})$

Where, $\mathrm{EBV}=$ estimated breeding value, $\mathrm{RA}=$ relative accuracy, $\mathrm{n}=$ total of progeny per sire, $\mathrm{R}$ $=0.25$ (half-sib correlation), $\mathrm{c}=0.10$ (correlation assumed) or 0.00 (no correlation assumed), $\overline{\mathrm{P}}=$ mean of progeny performance for each sire, $\overline{\bar{P}}=$ population mean, $\mathrm{P}=$ individual performance.

\section{Results}

Means with standard errors of progeny growth performance of individual Aceh bulls are presented in Table 2. Variation in body weights of the progeny of selected four bulls were found significant at weaning weight (WWC), yearling weight (YWc) and final weight (FWc). Birth weight 


\section{Evaluation of Aceh Cattle}

of the progeny of different bulls varied non significantly $(P>0.05)$. The highest body weight values such as: BWc $(13.87 \pm 0.85 \mathrm{~kg})$, WWC $(52.83 \pm 9.24 \mathrm{~kg})$, YWc $(82.46 \pm 15.86 \mathrm{~kg})$, FWc $(115.21 \pm 26.62 \mathrm{~kg})$ was observed of the progeny of bull number 0752 where the lowest BWc $(12.76 \pm 0.91 \mathrm{~kg})$, WWc $(42.11 \pm 7.38 \mathrm{~kg}), \quad$ YWc $(65.36 \pm 13.20 \mathrm{~kg})$, FWc $(89.45 \pm 15.39 \mathrm{~kg})$ was found of the progeny of bull number 004. In other words, the body weight of the progeny of bull number 0752 was higher compared to others. Heritability $\left(h^{2}\right)$ estimates of WWc, YWc and FWc were more than 0.40 (Table 3) which were in high category $\left(\mathrm{h}^{2}\right.$ value higher than $0.30)$. The $h^{2}$ value of BWc was 0.01 which was in low category ( $h^{2}$ value lower than 0.10 ). In this study standard error (SE) values were higher than $\mathrm{h}^{2}$.

Breeding bulls of the present study were ranked according to their estimated breeding values (EBV) from progeny's growth performance which are presented in Table 4 . The highest relative accuracy (RA) was found on BWc trait (1.21 and 1.78). However, selection for breeding bulls based on progeny's BWc was not effective because of lower $h^{2}$ of BWc.

However, the breeding bulls rank based on BWC and WWC was similar. The EBV value $(\mathrm{kg})$ for breeding bull ranged from 13.21 to 13.31 (BWC), 40.52 to 54.24 (WWC), 63.81 to 83.99 (YWC), 85.85 to 119.08 (FWc). According to the EBV of WWc bull number 0752 was best, followed by bull number 0751, 001 and 004. Breeding bull number 0752 produced three best candidate bulls (100412, 100317, 100811) and produced one best heifer (100408) based on their EBV rank (Table 5).

Table 1. Feed nutrient standard (\%) for Aceh bull and cow at the breeding station

\begin{tabular}{cccccccccc}
\hline Group & WC & Ash & CP & Fat & Ca & P & NDF & UDP & TDN \\
\hline Bull & 14 & 12 & 12 & 6 & $0.5-7.0$ & $0.5-0.6$ & 30 & 4.2 & 65 \\
Cow & 14 & 12 & 14 & 6 & $0.8-1.0$ & $0.6-0.8$ & 35 & 5.6 & 65 \\
\hline
\end{tabular}

WC, water content; $C P$, crude protein; Ca, calcium; $P$, phosphor; NDF, neutral detergent fiber; UDP, undigestible protein; TDN, total digestible nutrient

Table 2. Means and standard errors of progeny body weight of individual Aceh bulls

\begin{tabular}{llcccc}
\hline \multirow{2}{*}{ Bull ID } & $\mathrm{N}$ & \multicolumn{4}{c}{ Progeny body weight $(\mathrm{kg})$} \\
\cline { 3 - 6 } & & \multicolumn{1}{c}{ BWc } & WWc & YWc & FWc \\
\hline 001 & 13 & $13.11^{\mathrm{ab}} \pm 1.66$ & $48.00^{\mathrm{ab}} \pm 9.95$ & $74.67^{\mathrm{ab}} \pm 17.18$ & $102.23^{\mathrm{ab}} \pm 20.95$ \\
004 & 13 & $12.76^{\mathrm{a}} \pm 0.91$ & $42.11^{\mathrm{b}} \pm 7.38$ & $65.36^{\mathrm{b}} \pm 13.20$ & $89.45^{\mathrm{b}} \pm 15.39$ \\
0751 & 13 & $13.25^{\mathrm{ab}} \pm 0.92$ & $48.24^{\mathrm{b}} \pm 11.11$ & $73.37^{\mathrm{b}} \pm 17.85$ & $100.58^{\mathrm{b}} \pm 26.13$ \\
0752 & 13 & $13.87^{\mathrm{b}} \pm 0.85$ & $52.83^{\mathrm{c}} \pm 9.24$ & $82.46^{\mathrm{c}} \pm 15.86$ & $115.21^{\mathrm{c}} \pm 26.62$ \\
Total & 52 & $13.25 \pm 1.18$ & $47.80 \pm 10.00$ & $73.97 \pm 16.79$ & $101.87 \pm 23.91$ \\
\hline
\end{tabular}

Means with different superscripts in the same column differed significantly $(P<0.05) ; B W c$, corrected birth weight; WWc, weaning weight at 205 days of age; YWc, yearling weight at 365 days of age; FWc, final weight at 550 days of age; $N$, observations

Table 3. Heritability $\left(\mathrm{h}^{2}\right)$ of body weights of Aceh cattle at the breeding station

\begin{tabular}{lcccc}
\hline \multicolumn{1}{c}{ Growth trait } & $\mathrm{N}$ (bull) & $\mathrm{N}$ (progeny) & $\mathrm{h}^{2}$ & $\mathrm{SE}$ \\
\hline Corrected birth weight & 4 & 13 & 0.01 & 0.27 \\
Weaning weight at 205 days & 4 & 13 & 0.48 & 0.60 \\
Yearling weight at 365 days & 4 & 13 & 0.40 & 0.55 \\
Final weight at 550 days & 4 & 13 & 0.49 & 0.60 \\
\hline
\end{tabular}

SE, standard error; $N$, total observations 
Putra el al. (2015) Bang. J. Amin. Sci. 44(2): 85- 91

Table 4. Estimated breeding values / EBV (rank) and relative accuracy (RA) of Aceh breeding bulls based on progeny body weight

\begin{tabular}{cccrr}
\hline \multirow{2}{*}{ Bull ID } & \multicolumn{5}{c}{ EBV $(\mathrm{kg})$} \\
\cline { 2 - 5 } & BWc & WWc & \multicolumn{1}{c}{ YWc } & FWc \\
\hline 001 & $13.24(3)$ & $48.06(3)$ & $74.80(2)$ & $102.33(2)$ \\
004 & $13.21(4)$ & $40.52(4)$ & $63.81(4)$ & $85.85(4)$ \\
0751 & $13.25(2)$ & $48.36(2)$ & $73.26(3)$ & $100.17(3)$ \\
0752 & $13.31(1)$ & $54.24(1)$ & $83.99(1)$ & $119.08(1)$ \\
\hline Relative accuracy & & & 0.98 & 0.94 \\
\hline C = 0.10 & 1.21 & 0.95 & 1.22 & 1.15 \\
\hline
\end{tabular}

BWc, corrected birth weight; WWc, weaning weight at 205 days of age; YWc, yearling weight at 365 days of age; FWc, final weight at 550 days of age

Table 5. Estimated breeding value (EBV) of top ten Aceh cattle based on their own weaning weight (WWC) at 205 days of age

\begin{tabular}{|c|c|c|c|c|c|c|}
\hline \multirow{2}{*}{ Rank } & \multirow{2}{*}{ Cattle ID } & \multirow{2}{*}{ Sex } & \multicolumn{2}{|c|}{ Parents ID } & \multirow{2}{*}{ WWc $(\mathrm{kg})$} & \multirow{2}{*}{ EBV $(\mathrm{kg}$} \\
\hline & & & Bull & Cow & & \\
\hline 1 & 100412 & $\bar{M}$ & 0752 & 0745 & 69.30 & 10.32 \\
\hline 2 & 100526 & $\mathrm{~F}$ & 001 & 0714 & 67.91 & 9.65 \\
\hline 3 & 100520 & M & 0751 & 170 & 67.35 & 9.38 \\
\hline 4 & 100408 & $\mathrm{~F}$ & 0752 & 0655 & 62.48 & 7.04 \\
\hline 5 & 100317 & M & 0752 & 0643 & 61.87 & 6.75 \\
\hline 6 & 100515 & M & 004 & 1288 & 60.64 & 6.16 \\
\hline 7 & 100811 & M & 0752 & 74 & 60.12 & 5.91 \\
\hline 8 & 100807 & $\mathrm{~F}$ & 0751 & 0720 & 58.63 & 5.20 \\
\hline 9 & 100302 & $\mathrm{~F}$ & 0751 & 0748 & 58.23 & 5.01 \\
\hline 10 & 100805 & M & 0751 & 0725 & 57.99 & 4.89 \\
\hline
\end{tabular}

M, male; $F$, female

However, selection for breeding bulls based on progeny's BWc was not effective because of lower $\mathrm{h}^{2}$ of BWc. However, the breeding bulls rank based on BWC and WWC was similar. The EBV value $(\mathrm{kg})$ for breeding bull ranged from 13.21 to 13.31 (BWc), 40.52 to 54.24 (WWc), 63.81 to 83.99 (YWC), 85.85 to 119.08 (FWc). According to the EBV of WWC bull number 0752 was best, followed by bull number 0751, 001 and 004 . Breeding bull number 0752 produced three best candidate bulls $(100412,100317,100811)$ and produced one best heifer (100408) based on their EBV rank (Table 5).

\section{Discussion}

Average body weight $(\mathrm{kg})$ of the progeny from four breeding bulls were $13.25 \pm 1.18\left(\mathrm{BW}_{\mathrm{C}}\right)$, $47.80 \pm 10.00\left(W W_{C}\right), 73.97 \pm 16.79\left(Y_{C}\right)$ and
$101.87 \pm 23.91\left(F W_{C}\right)$. Umartha (2013) observed the BW of Aceh calves was $15.90 \mathrm{~kg}$ (male) and $14.75 \mathrm{~kg}$ (female). Jamaliah (2012) observed the WW of Aceh cattle was $50.88 \mathrm{~kg}$ (male) and $44.02 \mathrm{~kg}$ (female). Abdullah et al. (2006) reported that the average $\mathrm{YW}$ of Aceh cattle was $123,34 \mathrm{~kg}$ (male) and $116,70 \mathrm{~kg}$ (female). Averages of Aceh body weight in this study were lower than the other researches and may be caused by differences in management, feed, climate and season during the research. Based on the FW ( \pm 1.5 years), Aceh cattle is the smallest cattle in Indonesia. The average YW of several breed cattle in Indonesia such as Bali $(136.35 \pm 2.92 \mathrm{~kg})$,Brahman cross (254.32 $47.91 \mathrm{~kg}$ ) and Madura were $209 \mathrm{~kg}$ (Gunawan and Jakaria 2011; Duma and Mobius 2008; Wijono and Bambang 2004). The heritability 


\section{Evaluation of Aceh Cattle}

value of BWc in this study was 0.01 (low category) and similar to Bali cattle (0.09) as reported by Andoyo et al. (2011). Yusran et al. (1995) and Suhada et al. (2009) reported that $\mathrm{h}^{2}$ value of BW in Madura cattle was 0.40 (high category) and Simmental (0.11) was medium category $\left(0.1<h^{2}<0.30\right)$. Heritability value of WW and YW on several beef cattle in Indonesia such as Bali (0.33 and 0.43) Brahman crossbred (0.37 and 0.44) and Madura (0.87 and 0.27) respectively (Gunawan and Jakaria 2011; Duma and Mobius 2008; Karnaen 2008). The high category on heritability value of WWc, YWc and FWc indicated that the genetic variance of each traits were large. Meanwhile body weight performance was more than $30 \%$ affected by genetic variance. Selection to breeding bulls based on these traits could improve their weight performance. Higher standard error (SE) than $h^{2}$ caused by less number of observation (offspring) for each bull. Based on the weight performance, cattle number 0752 was the best breeding bull at the breeding centre. This cattle could be recommended for natural insemination or produce the straw. The higher relative accuracy (RA) was showed on BWc. However, lower $h^{2}$ of BWC indicated that these trait was not accurate as selection criterion. The lower value of RA (RA $<1.00$ ) on trait indicate that these trait were not accurate as selection criterion, so more samples (progeny) would be needed for analysis (Hardjosubroto 1994). Breeding bull number 004 was the poorest because of lower EBV values on each traits. Only one progeny from breeding bull 004 included to the top six breeding bulls (rank $6)$. Based on the progeny performance, breeding bull number 0752 and its progeny were recommended for breeding stock in the breeding center. Yusran et al. (1995) reported that EBV of BW for top best Madura bulls was $15.83 \mathrm{~kg}$. Therefore, Salces et al. (2008) reported that the highest EBV of BW and WW were $34.10 \mathrm{~kg}$ and $186,70 \mathrm{~kg}$ respectively and reached in Brahman cattle.

\section{Conclusion}

Selection of superior breeding bulls can aid in high quality progeny production. Bull evaluation is generally aimed at selecting first few top ranking bulls. The WWC trait could be used as selection criterion. Cattle number 0752 and 0751 were the best breeding bulls in this station and to perform this research work.

\section{Acknowledgement}

We gratefully acknowledged the Indrapuri's Breeding and Forages Centre (IBFC) of Aceh Cattle for financial support.

\section{References}

Abdullah MAN, Noor RR, Martojo M, Solihin DD, Handiwirawan E (2006). The phenotypic variability of Aceh cattle in Nanggroe Aceh darussalam. Journal of Indonesian Tropical Animal and Agriculture. 32: 11-21.

Andoyo S, L Hakim, Suyadi, Ismudiono (2010). Evaluation of Bali cattle bull based on Animal Model method. Symposium on Animal Farming and Veterinary Technology. Bogor, Indonesia, Proc. Nat. Animal and Veterinary Sciences. P. 9-16.

Duma Y, Mobius T (2008). The potential of selection response of growth traits of Brahman cross in the Billa River Ranch, South Sulawesi. Symposium on National Beef Cattle. Palu, Indonesia, Proc. Nat. Beef Cattle. 24: 216-224.

Gunawan A, Jakaria (2011). Genetic and nongenetics effect on birth, weaning and yearling weight of Bali cattle. Journal of Animal Science and Technology. 34: 93-98.

Becker WA (1992). Manual of Quantitative Genetics. 4th Edn., Washington State University, Washington, USA. P. 97-99

Falconer DS, Mackay TF (1996). Introduction to Quantitative Genetics. 4th Edn. North Canada University, Prince John, Canada. p. 68-70.

Hardjosubroto W (1994). Applied of Animal Breeding. Grasindo, Jakarta, Indonesia. p. 146-150

Jamaliah (2012). Management of Aceh Calves at The Breeding Centre. Handout of Indrapuri's Breeding and Forages Centre (IBFC) of Aceh Cattle. P. 25

Karnaen (2008). Estimation of heritability, genotypic and phenotypic correlations of 
Putra el al. (2015) Bang. J. Amin. Sci. 44(2): 85- 91

body weight traits in Madura cattle. Journal of Indonesian Tropical Animal and Agriculture. 33: 191-196.

Salces AJ, K Moore, D Johnston, H Graser, P Limson, T Tanglao (2008). Genetic parameter estimation of Philippine Brahman cattle (Bos indicus Linn.). Philippine J ournal of Veterinary and Animal Science. 34: 99-106.

Suhada H, Sumadi, N Ngadiono. (2009). Estimation of genetic parameters of production characteristics on Simmental cattle at Balai Pembibitan Ternak Unggul Padang Mengatas, West Sumatera. Bulletin of Animal Science. 33: 1-7.
Umartha BA (2013). The characteristic of Aceh Cattle. Unsyiah University Press. p. 35.

Warwick EJ, Jovita WA, Wartomo H (1990). Animal Breeding. Gadjah Mada University Press, Yogyakarta, Indonesia. p. 157-160.

Wijono DB, Bambang S (2004). The potential of genetic diversity of Madura cattle. Symposium on National Beef Cattle. Bogor, Indonesia, Proc. Nat. Beef Cattle. 19: 4252.

Yusran MA, M Komarudin, DB Wijono (1995). The evaluation on breeding value of Madura candidate bulls through progeny-test program. Grati's J ournal of Animal Science. 4: 17-23. 